\title{
Between-habitat differences in burrow characteristics and trophic modes in the southwestern Atlantic burrowing crab Chasmagnathus granulata
}

\author{
Oscar Iribarne*, Alejandro Bortolus, Florencia Botto
}

Departamento de Biología (FCEyN), Universidad Nacional de Mar del Plata, Funes 3250 (7600) Mar del Plata, Argentina

\begin{abstract}
Burrow characteristics, food type, and feeding habits of the SW Atlantic burrowing crab Chasmagnathus granulata were compared between individuals living in mud flats and in Spartinadominated marshes. Burrows were shorter $(x=19.7 \mathrm{~cm}, \mathrm{SD}=5.8, \mathrm{n}=54)$ and more dynamic (entrance displacement: $x=3.2 \mathrm{~cm} \mathrm{~d}^{-1}, \mathrm{SD}=1.7, \mathrm{n}=21$ ) in mud flats than in Spartina-dominated areas (length: $x=41 \mathrm{~cm}, \mathrm{SD}=12, \mathrm{n}=78$; no entrance displacement). Sediment turnover rate was much higher in mud flats $\left(x=5.9 \mathrm{~kg} \mathrm{~m}^{-2} \mathrm{~d}^{-1}\right)$ than in Spartina-dominated areas $\left(x=2.4 \mathrm{~kg} \mathrm{~m}^{-2} \mathrm{~d}^{-1}\right)$. Burrow shape differed between areas, being straight, near-vertical tunnels in the vegetated area, but oblique (average angle to vertical $=60^{\circ}, \mathrm{SD}=16^{\circ}, \mathrm{n}=110$ ), and having a funnel-shape entrance and a much larger diameter in mud flats. Stomach contents also differed between habitats. Pieces of plants dominated contents in the vegetated area, while sediment (with polychaetes, diatoms, ostracods, and nematodes) dominated in the mud flats, indicating that crabs are mainly deposit feeders in the mud flats and herbivorous in the Spartina-dominated areas. This pattern suggests that the heuristic model relating burrow architecture to trophic modes previously proposed for fossorial thalassınidean shrimps applies to individuals of a $C$. granulata population. The burrow content showed higher organic content and vegetal parts in the vegetated area than in the other area. Burrows in the mud flat showed a significantly higher abundance of nematodes and ostracods. Due to their hydrodynamic characteristics and content, burrows in the mud flats may work as passive traps for sediment and organic matter. Given the extensive intertidal area inhabited by C. granulata in SW Atlantic estuaries, and the location of their burrows (between marshes and the open estuary), these burrows may work as traps for detritus, thus reducing the export rate of organic matter from marshes.
\end{abstract}

KEY WORDS: Spartina marsh Chasmagnathus granulata Burrowing Herbivory

\section{INTRODUCTION}

Benthic fauna play an important role in the sedimentary process, leading to important changes in marsh characteristics (Frey et al. 1978, Bertness 1985). The fauna of mud flats and creeks include many deposit and filter feeders that modify sediment particle size and chemistry (Levinton 1989). Their burrowing activities may have considerable effects on soil aeration and on growth and distribution of the flora (e.g. Spartina

\footnotetext{
•E-mail: osiriba@mdp.edu.ar
}

alterniflora; Bertness \& Miller 1984, Bertness 1985). Particular attention has been given to the importance of crabs as habitat modifiers in salt marshes (e.g. Montague 1980, Bertness 1985). Burrowing crabs may be present in large numbers in these environments (e.g. Boschi 1964, Bertness \& Miller 1984), significantly influencing microtopography, sediment chemistry and drainage (Bertness 1985). Sediment disturbance resulting from the foraging and burrowing activities of decapods may have direct and indirect impacts on other species (e.g. Thrush 1988, DePatra \& Levin 1989, Warwick et al. 1990). Species that are sensitive to burial or disturbance may suffer higher mortality due to 
crab activities (e.g Kneib 1991, Billick \& Case 1994), or predators may be attracted to areas where infauna are exposed due to sediment reworking (e.g Auster \& Crockett 1984)

The interpretation of autoecological characteristics from physical structures has been an active area of research during the past few years. Suchanek (1985) and Griffis \& Suchanek (1991), comparing thalassinid shrimps, identified species-specific burrow architecture suggesting that burrow morphology reflects the feeding modes of the organism, and proposed a heuristic model relating burrow architecture to trophic modes. Although this classification has been criticized due to the lack of flexibility to account for intraspecific variations (i.e. Nickell \& Atkinson 1995, Rowden \& Jones 1995), the important value of this approach was to point out the interrelationship between feeding modes, burrow architecture and effects on sediment dynamics.

The crab Chasmagnathus granulata, one of the most abundant macroinvertebrates on salt marshes of the southwestern Atlantic (Boschi 1964, Capitoli et al. 1977, 1978, Botto \& Irigoyen 1979, D'Incao et al. 1990, Spivak et al. 1994), is also a burrowing species that inhabits the intertidal, from the soft bare sediment flats to areas vegetated by the cordgrass Spartina densiflora (Boschi 1964, D'Incao et al. 1988, Spivak et al. 1994). These crabs excavate and maintain semipermanent open burrows (Boschi 1964. Spivak et al. 1994) and, as suggested for other burrowing species (e.g. Uca spp.; Teal \& Kanwisher 1961), their burrowing activity may oxygenate marsh soil, enhance soil drainage, and modify sediment meiofaunal abundance. C. granulata burrows can extend up to $1 \mathrm{~m}$ into the marsh sediment and density can be as high as 60 crabs $\mathrm{m}^{-2}$ (pers. obs.) Given their high density and the important role of deposit feeding on sediment composition (e.g. Rhoads 1967), this species is likely to play a key role in marsh production and integrity. Despite these facts, no attention has been directed to understanding the impact of their burrowing and deposit feeding activities on salt marsh community or sediment dynamics. On the basis of stomach content analysis of individuals of unidentified origin, this species is described as omnivorousdetritivorous (Botto \& Irigoyen 1979, D'Incao et al 1990). However analyses of gut contents without regard to the behavior and feeding patterns may lead to a misunderstanding of dietary scope and the species' potential impact within different habitats (see Kneib 1995).

In previous studies, it has been observed that burrows of Chasmagnathus granulata vary in size and shape in intertidal mud flats compared with dry mud in the Spartina densiflora marsh (Olivier et al. 1972a, b, Goya 1988). Our observations also suggest an associa- tion between trophic mode and burrow architecture. Crabs living in creeks and channels show shallow burrows with large entrances and surface sediment mounds, while crabs living in the $S$. densiflora marsh show deep burrows with small entrances and often without surface sediment mounds. Preliminary observations on stomach contents of crabs living in creeks show only mud, while crabs obtained from marsh areas show fragments of vascular plants. This suggests that heuristic models that relate feeding mode, burrowing activity and burrow architecture (as proposed by Griffis \& Suchaneck 1991) also apply for conspecifics within the same population of C. granulata, which are deposit feeders in mud flats (creeks and channels) and herbivorous-detritivorous in the marsh area. In this work we evaluate this general hypothesis by investigating if burrow architecture, burrow dynamics, sediment turnover rate, and feeding modes vary between individuals living in open mud flats and those living in the marsh area dominated by the cordgrass $S$. densiflora.

\section{METHODS}

The study was performed in the Mar Chiquita coastal lagoon (Argentina, $37^{\circ} 32^{\prime}$ to $37^{\circ} 45^{\prime} \mathrm{S}, 57^{\circ} 19^{\prime}$ to $57^{\circ} 26^{\prime} \mathrm{W}$ ) from spring 1995 to autumn 1996 . The study site is a body of brackish water (approximately $46 \mathrm{~km}^{2}$ ) affected by low amplitude ( $\leq 1 \mathrm{~m}$ ) tides (e.g. Lanfredi et al. 1987, Spivak et al. 1994) and characterized by mud flats surrounded by a large cordgrass Spartina densiflora area (Olivier et al. 1972a, b, Fasano et al. 1982). Two sites located $20 \mathrm{~m}$ apart were compared during this study: (1) tidal mud flats and (2) a marsh area dominated by cordgrasses.

To investigate variations between habitats in burrow shape, castings (made with gypsum plaster of Paris) of 20 burrows of average size in each habitat type (entrance diameter 4.5 to $6.5 \mathrm{~cm}$ in mud flats, and 2.0 to $4.0 \mathrm{~cm}$ in the marsh area) were made. After a hardening time of $72 \mathrm{~h}$, casts were hand-excavated from the sediment, washed free of sediment, and allowed to dry and harden in a heated room. Then, a visual description in terms of entrance and tunnel shape was made.

For the quantitative comparison of burrows between habitats, burrows were sampled following 2 different designs. A sample of burrow was obtained by randomly placing ten $1 \mathrm{~m}^{2}$ quadrats in each habitat, counting burrow entrances and measuring their diameter (major axis and minor axis). The null hypothesis of no difference in the size frequency distribution of maximum entrance diameters between habitats was tested using a Kolmogorov-Smirnov test (Zar 1984) To investigate differences in shape of burrow entrances, the 
ratio between the major axis (maximum diameter) divided by the minor axis (minimum diameter) was calculated in each area. The null hypothesis of no difference in the distribution of ratios between habitats was evaluated with a Kolmogorov-Smirnov test (Zar 1984).

To investigate the relationship between diameter of burrow entrances and burrow volume, 40 burrows from each habitat were sampled, covering homogeneously the size range of opening diameters found in each site, and measuring: (1) major and minor axis entrance diameter (precision: $\pm 0.1 \mathrm{~mm}$ ), and (2) burrow volume (measured filling them with a known volume of fine-grained dry sand). The null hypothesis of no difference between habitats in the relationship between entrance diameter and burrow volume was evaluated by comparing the slopes of the relationship of burrow volume and burrow diameter (major axis) for each habitat (Zar 1984). Data were log-transformed to comply with the assumptions of linearity of a simple linear regression (Zar 1984). To investigate differences in burrow inclination in relation to the marsh or open mud floor, a $1 \mathrm{~m}$ long stiff wire was inserted into the burrow entrance and its angle measured in relation to the vertical plane (marsh-floor or open mud). The null hypothesis of no difference in frequencies of a range of angles was evaluated with a chi-squared test (Zar 1984).

Burrow entrances were also characterized in relation to their shape. When the openings of burrows were funnel-shaped, we measured the maximum diameter of the exterior part of the burrow entrance, the diameter of the shaft and the depth of the funnel (distance between the plane generated by the burrow entrance and the plane generated by the end of the funnel beginning of the tunnel). We also measured the total length of each burrow. The null hypotheses of no relationship between external maximum diameter and diameter of the shaft, external maximum diameter and depth of the funnel, and diameter of the shaft and funnel depth were evaluated by a correlation analysis (Zar 1984). The null hypothesis of no difference between zones in mean burrow length was evaluated by a $t_{c}$ test (Zar 1984). Here and in all further cases means were compared with the Welch-approximation $t$-test $\left(t_{c}\right)$ to account for differences in variances (Zar 1984).

To study differences between zones in burrow dynamics, and sediment turnover rate, 100 burrows (of average size) were identified in each area. Entrances of these burrows were measured (maximum diameter). and spatially located (centered) in relation to 4 fixed points positioned $20 \mathrm{~cm}$ from the burrow entrance. Daily measurements of location of burrow entrance in relation to the fixed points and amount of sediment removed were obtained for a period of $30 \mathrm{~d}$ (February 2 to March 5) at each site. A $t_{c}$-test analysis (Zar 1984) was used to test the null hypothesis of no difference in the mean daily burrow displacement (linear distance in $\mathrm{cm}$, between initial and final position) between zones.

Amount of sediment removed by crabs per day in each habitat was also quantified by weighing (wet weight) the new sediment that appeared each day in the mound around the burrow entrance (precision $\pm 1 \mathrm{~g}$ ). However it is important to note that, although tidal energy or wind transport in this area is low, we may have underestimated the actual values in the open mud flat because measurements of sediment mounds were obtained after a full tidal cycle. The null hypothesis of no relationship between diameter of the burrow entrances and mound wet weight was evaluated by a correlation analysis (Zar 1984). The null hypothesis of no difference between habitats in daily sediment turnover rate per burrow as a function of entrance diameter was evaluated by comparing the slopes of the relationship between sediment weight and maximum diameter of the burrow entrance (Zar 1984)

Position of burrow mounds in relation to the burrow opening of at least 100 randomly selected burrows per site, in 3 parts of the channel with different orientation (main channel orientation of site $\mathrm{A}$ : $90^{\circ}$ to $270^{\circ}$; site $\mathrm{B}$ : $20^{\circ}$ to $200^{\circ}$; site $\mathrm{C}$ : $70^{\circ}$ to $250^{\circ}$ ), were determined during low tide. Orientation was defined as the bearing of a line between the mound and the burrow entrance. The null hypothesis of no preferential direction was evaluated with a chi-squared test (Zar 1984). Since preferential orientation of mound locations in relation to burrow entrances were found, the area around the burrow was divided in 2 semicircles, one in the upstream direction and other in the downstream direction. The null hypothesis of no preferential location of burrow mounds in relation to the upstream or downstream current was evaluated by a binomial test (Conover 1980).

Burrow contents were sampled in each site by using a $1.5 \mathrm{~m}$ long hose to suck approximately $100 \mathrm{ml}$ of water and sediment from the deepest part of the burrow. Forty replicates were obtained from each site, sieved through a $100 \mu \mathrm{m}$ screen, and the retained material was identified with a binocular microscope $(40 \times)$. Individuals found in each sample were standardized per unit of volume of sediment [number of organisms (volume of sediment) ${ }^{-1}$ ]. The null hypothesis of no difference between habitats in abundance of each species in the burrow content was evaluated with a $t_{c}$-test (Zar 1984). An additional 20 samples were obtained using the same procedure, dried at $60^{\circ} \mathrm{C}$ for $4 \mathrm{~d}$, and ash free dry weights (AFDW) determined after combustion at $500^{\circ} \mathrm{C}$ for $24 \mathrm{~h}$. The percentage difference between dried weight and AFDW was calculated and 
then the null hypothesis of no difference between habitats was evaluated with a $t_{c}$-test (Zar 1984)

To evaluate if feeding modes differed between habitats, 100 crabs were sampled at low tide from each habitat, immediately killed and their stomachs preserved in $5 \%$ formalin. The volume of plants remains and sediment in each stomach was measured by placing the stomach contents, diluted in $5 \%$ formalin, into a $5 \mathrm{ml}$ calibrated flask $(0.1 \mathrm{ml})$, and allowing the content to sink for $4 \mathrm{~h}$. The null hypothesis of no difference between habitats in volume of plant debris or sediment was evaluated with a $t_{c}$-test (Zar 1984). Comparison between sediment and plants volume was not performed because, due to their lower specific weight, plants are less closely packed than sediment; thus plant volumes found with our measurement procedure are not the minimum volumes at which they can be held in the stomach.

\section{RESULTS}

Casting and excavations showed that burrows in both habitats are simple, with a single shaft or tunnel, mainly without branches and always reaching the water table. However, burrows differ in shape. Burrows located in mud flats are short, with an enlarged funnel-like opening which terminates in a sediment mound. Burrows in the marsh area are straight, long tunnels, usually with an enlarged chamber at the end approximately 2 times the tunnel diameter

In the mud flats the minor and major external axes of burrow entrances were usually different but correlated $\left(\mathrm{r}^{2}=0.85, \mathrm{n}=54, \mathrm{p}<0.05 ;\right.$ Fig. 1A). The depth of the funnel was significantly correlated with the diameter of the burrow entrance $\left(r^{2}=0.57, n=54, p<0.05\right.$; Fig. 1B) and the length of the burrow was also correlated to the major axis of the burrow entrance $\left(\mathrm{r}^{2}=\right.$ $0.29, n=54, p<0.05$; Fig. 1D). However, there was no significant correlation between burrow length and the entrance major axis in the marsh area $\left(\mathrm{r}^{2}=0.0002, \mathrm{n}=\right.$ 76. $\mathrm{p}>0.05$ ). In the mud area the shaft diameter was also correlated with the external major axis $\left(r^{2}=0.27\right.$, $\mathrm{n}=54, \mathrm{p}<0.05 ; \mathrm{Fig} 1 \mathrm{C})$. Burrows in the Spartina marsh were significantly longer $(x=41 \mathrm{~cm}, \mathrm{SD}=12$, $\mathrm{n}=78$, up to $73 \mathrm{~cm}$ ) than burrows in the mud flat $(x=$ $22.8, \mathrm{SD}=56.6, \mathrm{n}=54$, up to $33 \mathrm{~cm}_{i} t_{\mathrm{c}}=13.5, \mathrm{df}=118$, $p<0.05$; Fig. 1D).

The size frequency distribution showed that maximum diameters of burrow openings in the marsh area were on average smaller $(x=26.6 \mathrm{~mm}, \mathrm{SD}=8.9 \mathrm{~mm}$, $\mathrm{n}=200$ ) than in the open mud flat $(x=52.8 \mathrm{~mm}, \mathrm{SD}=$ $17.8 \mathrm{~mm}, \mathrm{n}=200$; Kolmogorov-Smirnov: $d_{\max }=76, \mathrm{p}<$ 0.05; Fig 2A). Burrow entrances were mainly circular in the marsh area [mean ratio (major axis/minor axis) =

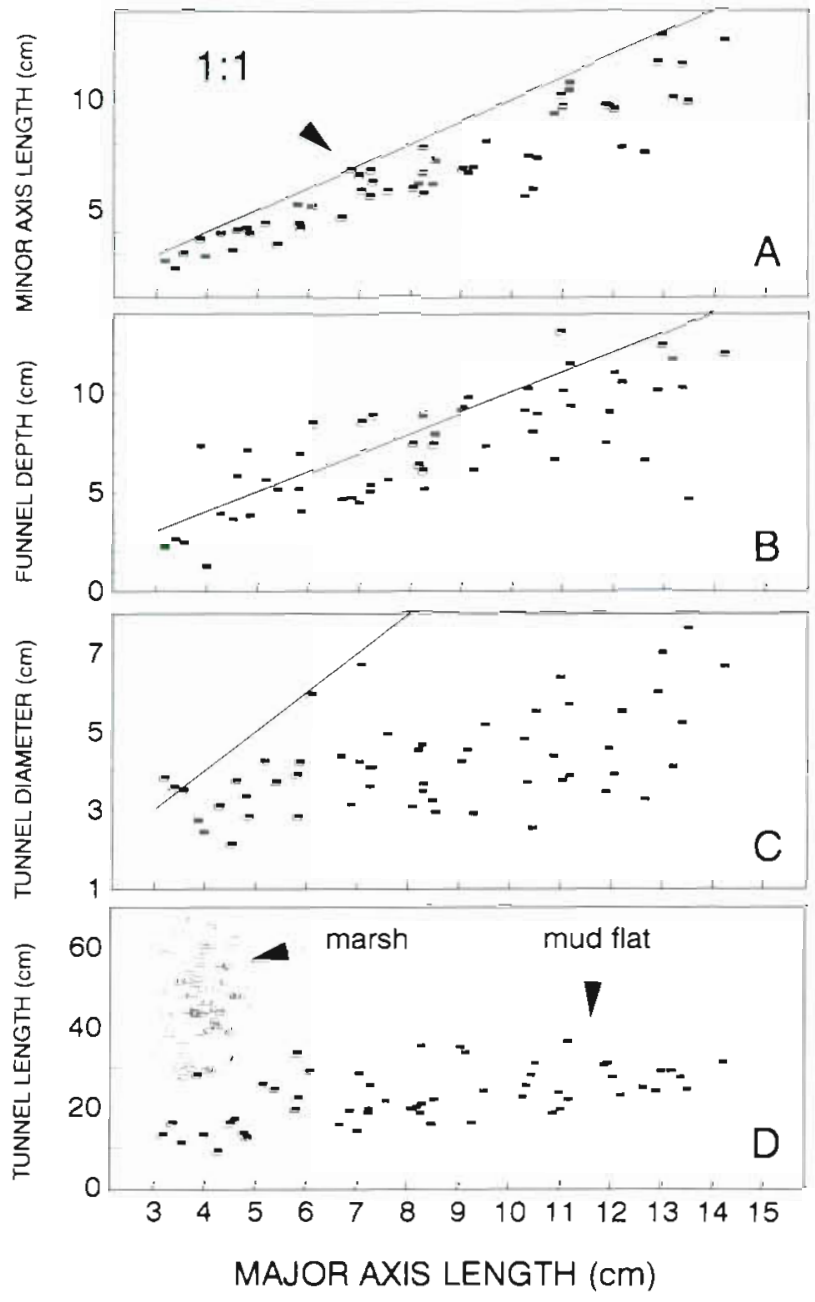

Fig. 1. Relationship between major axis length of burrow entrances and (A) minor axis length, (B) funnel depth, (C) tunnel diameter and (D) tunnel length for burrows sampled in both habitats. The line represents the 1:1 relationship. Sample sizes were 54 in the mud flat and 41 in the Spartina marsh

1.09, $\mathrm{SD}=0.17, \mathrm{n}=200 \mathrm{j}$ but asymmetric in mud flats (mean ratio (major axis $/$ minor axis) $=1.38, \mathrm{SD}=0.29$, $\mathrm{n}=200 \mathrm{Fig} .2 \mathrm{~B}]$. The difference in the frequency distribution of ratios was also statistically significant [Kolmogorov-Smirnov: $d_{\max }=57,\left(d_{\max }\right)_{0.05,15,200}=12$, $p<0.05$ The slopes of the relationship between opening diameters and burrow volume (log-transformed volume; Fig. 2C) were significantly different between habitats (mud flat: $b=0.01451, \mathrm{SD}=0.0026, \mathrm{n}=39$; marsh area: $b=0.0054, \mathrm{SD}=0.00187, \mathrm{n}=39 ; t_{c}=17.43$, $\mathrm{df}=76, \mathrm{p}<0.005)$. Burrow volumes for a given diameter in marsh areas were larger than in mud flats when openings were relatively small, but smaller for larger burrow openings (Fig. 2C) These differences were not related to the internal shape of the burrow, instead the larger volumes of burrow with larger openings were 

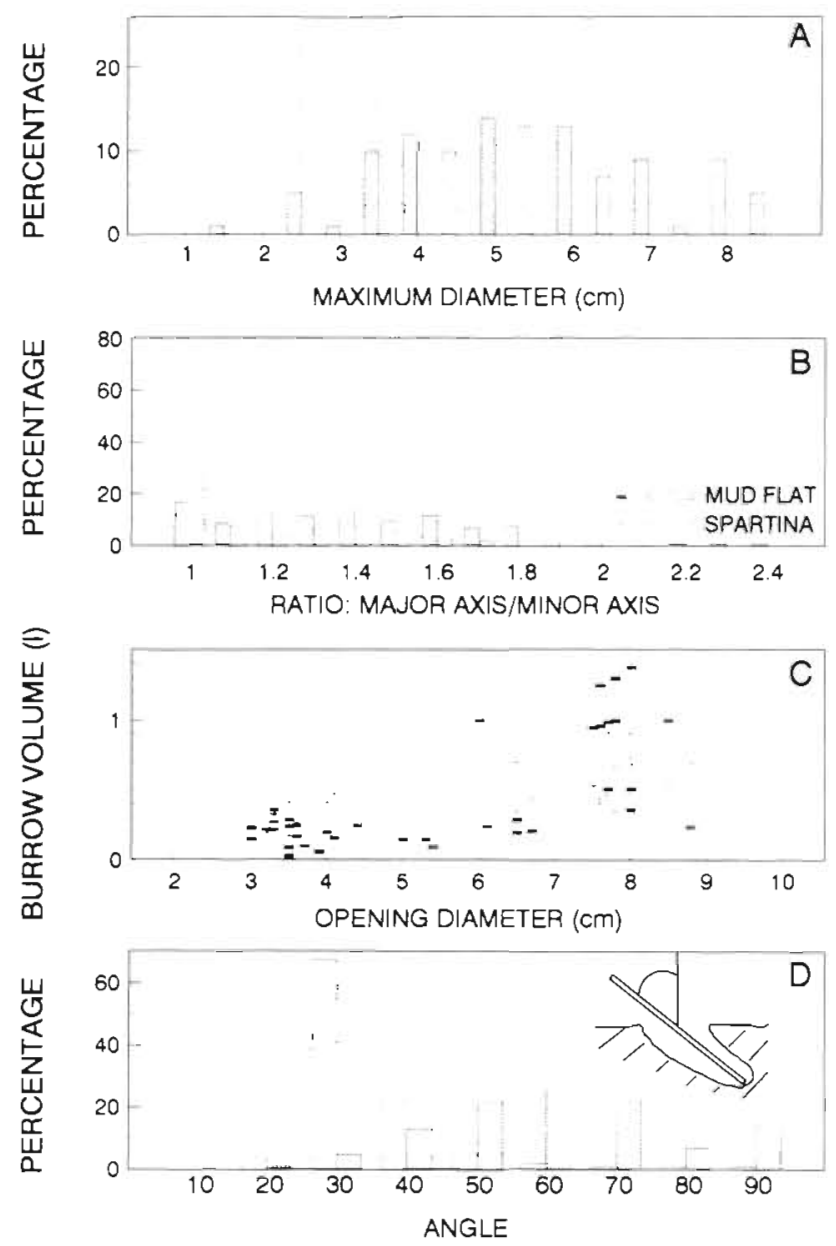

Fig. 2. Percentage distrubution of (A) maximum diameters of burrow entrances, (B) ratios major axis/minor axis $(\mathrm{n}=200)$, and (D) burrow angles (in relation to the vertical) in both habitats. (C) Relationship between burrow volume and opening diameter. Open bars: data from the Spartina marsh; shaded bars: data from the mud flats

mostly due to the enlarged entrance forming a funnellike depression instead of a small straight entrance. The burrow inclination, in relation to the vertical axis was greater in open mud flats $\left(x=60^{\circ}, \mathrm{SD}=16^{\circ}, \mathrm{n}=\right.$ 110), and significantly different from burrows in the marsh area $\left(x=33^{\circ}, \mathrm{SD}=11^{\circ}, \mathrm{n}=110_{i} \chi^{2}=930\right.$, $\chi^{2} 0.05,8=15.5, p<0.05$; Fig 2D) where they were almost perpendicular to the surface.

The continuous observations of burrows in open mud flats showed that only a small proportion of burrows $(-20 \%)$ were closed (Fig. $3 \mathrm{~A})$ during the experimental period. Burrows were much more dynamic in channels, in terms of percentage of active burrows per day $(x=79.5 \%, \mathrm{SD}=7.6 \%, \mathrm{n}=100)$, than in the marsh area $\left(x=32 \%, \mathrm{SD}=3 \%, \mathrm{n}=100 ; t_{\mathrm{c}}=58.1, \mathrm{df}=129, \mathrm{p}<\right.$ $0.05)$. There was no noticeable lateral movement in burrow openings located in the marsh area while mean lateral movement of burrow openings in mud flats was significantly higher, averaging $3.27 \mathrm{~cm} \mathrm{~d}^{-1}(\mathrm{SD}=1.7$, $\mathrm{n}=100 ; t_{\mathrm{c}}=19.2, \mathrm{df}=99, \mathrm{p}<0.05 ;$ Fig 3B). There was a significant relationship between amount of sediment removed per day and burrow opening diameter in mud flats $\left(r^{2}=0.89, n=35, p<0.005\right)$ and in the marsh area $\left(\mathrm{r}^{2}=0.46, \mathrm{n}=35, \mathrm{p}<0.05\right)$. However the amount of sediment removed as a function of burrow entrance diameter was higher in the mud flat area (slope of the relation of sediment weight to burrow entrance diameter: $b=3.7433, \mathrm{SD}=0.3262, \mathrm{n}=33$ ) than in the marsh area $\left(b=2.3604, \mathrm{SD}=0.4464, \mathrm{n}=34 ; t_{c}=-14.506, \mathrm{df}=60\right.$, $\mathrm{p}<0.05$; Fig. 4)

Location of sediment mounds around the burrow entrances in the open mud flat were significantly different from a random distribution at all sites (site $\mathrm{A}$ : $\chi^{2}=16.5, \mathrm{p}<0.05 ;$ site $\mathrm{B}: \chi^{2}=19.7, \mathrm{p}<0.05$; site $\mathrm{C}: \chi^{2}=$ 18.18, $\mathrm{p}<0.05)$. Mounds were preferentially located along the axis of the main channel (Fig. 5) with no preferential location in relation to the upstream or downstream side at site A (upstream $48 \%, \mathrm{n}=70$, binomial test: $\left.t_{1}=26, t_{2}=50, \mathrm{p}>0.05\right)$, and preferentially located downstream at the other 2 sites (site B: upstream $64 \%$, $\mathrm{n}=70$, binomial test: $t_{1}=27, t_{2}=43, \mathrm{p}<0.05$; site $\mathrm{C}$ : upstream $67 \%, \mathrm{n}=80$, binomial test: $t_{1}=31, t_{2}=49, \mathrm{p}<$ $0.05)$.
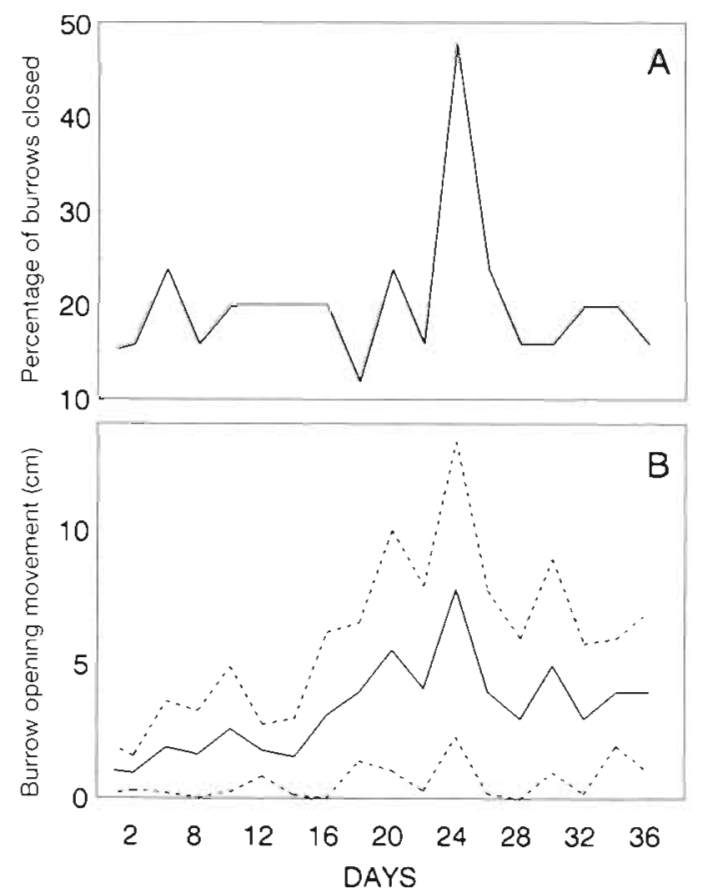

Flg. 3. Burrow activity in mud flats durng a period of $30 \mathrm{~d}$ when they were followed individually $(n=100)$. (A) Percentage of burrows closed each day; (B) mean ( \pm SD) burrow movement between days. Dashed lines represent \pm 1 SD 


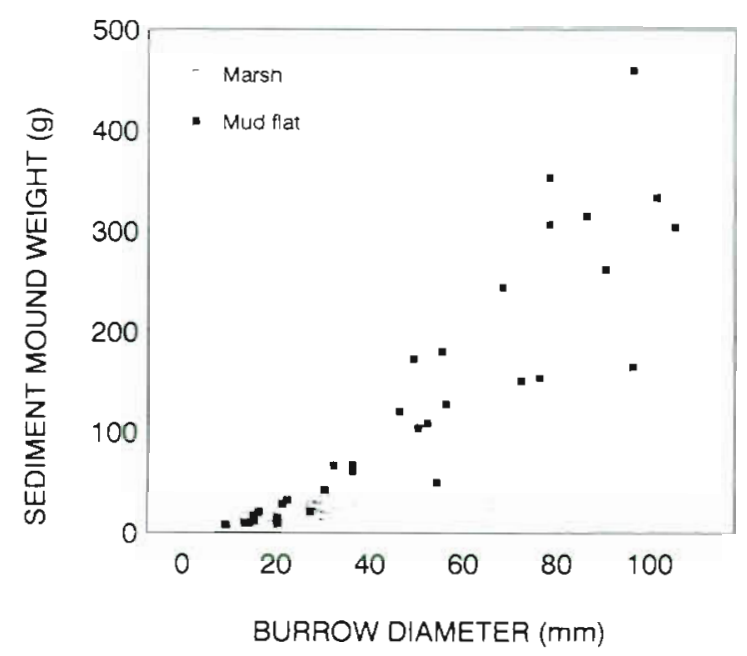

Fig. 4. Relationship between sedıment mound weight and burrow diameter for burrows in the Spartina marsh area $(\square$, $n=34)$ and the mud flat $(\mathbf{m}, \mathrm{n}=33$ )

Burrow contents differed between sites. Burrows in the Spartina marsh showed significantly lower densities of nematodes $\left(x=0.8\right.$ ind. $\left.\mathrm{mg}^{-1}, \mathrm{SD}=0.2, \mathrm{n}=20\right)$

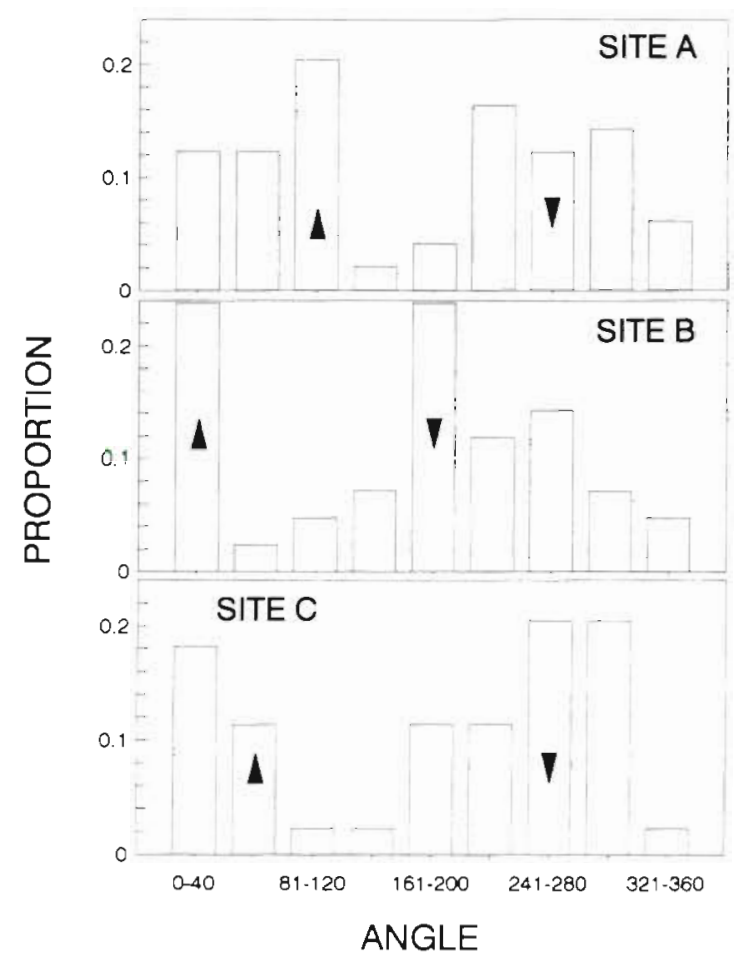

Fig. 5. Orientation of sediment mounds (in relation to burrow entrances) at the 3 sites (main channel orsentation of site $A$ : $90)-270^{\circ}, \mathrm{n}=70$; site $\mathrm{B}: 20^{\circ}-200^{\circ}, \mathrm{n}=70$; site C: $70^{\circ}-2.50^{\circ}, \mathrm{n}=$ 80). The $x$-axis represents the onentation angle where $0^{\circ}$ and $360^{\circ}$ is north. Arrows indicate mound located exactly $\left( \pm 20^{\circ}\right)$ upstream ( $\mathbf{\Lambda}$ ) or downstream ( $\mathbf{V}$ ) from the burrow entrance

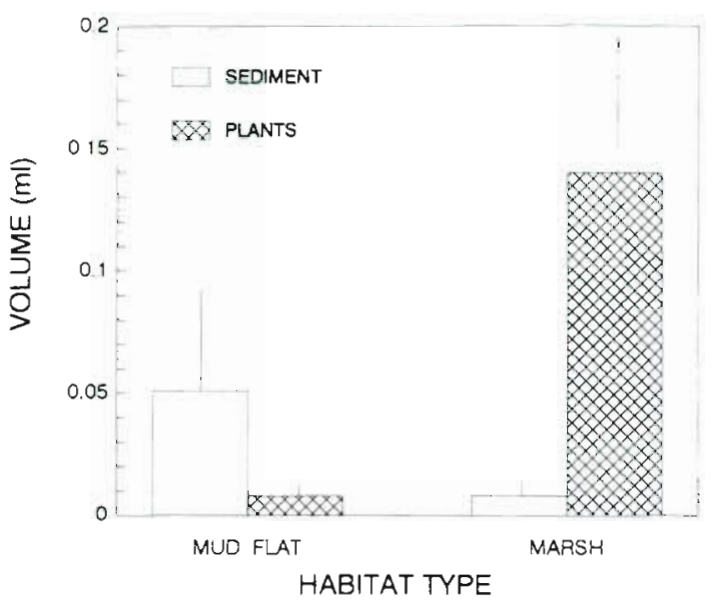

Fig. 6. Mean volume occupied by sediment (open bars) and macrophytes (crosshatched bars) of individuals collected in the mud flats $(n=40)$ and the Spartina marsh $(n=40)$. Lines above the bars represent $1 \mathrm{SD}$

and copepods $\left(x=0.08\right.$ ind. $\left.\mathrm{mg}^{-1}, \mathrm{SD}=0.09\right)$ than burrows in the mud flat (nematodes: $x=9.38$ ind. $\mathrm{mg}^{-1}$, $\mathrm{SD}=4.52, t_{\mathrm{c}}=8.48, \mathrm{df}=19, \mathrm{p}<0.05$; copepods: $x=$ 4.32 ind. $\mathrm{mg}^{-1}, \mathrm{SD}=5.48, t_{\mathrm{c}}=3.45, \mathrm{df}=19, \mathrm{p}<0.05$ ) Ostracods $\left(x=0.65\right.$ ind. $\left.\mathrm{mg}^{-1}, \mathrm{SD}=0.17, \mathrm{n}=20\right)$ and turbellarians $\left(x=0.12\right.$ ind. $\mathrm{mg}^{-1}, \mathrm{SD}=0.17, \mathrm{n}=20$ ) were only found in the open mud. Pieces of plants (probably Spartina leaf) were found in burrows from the marsh area, but not in burrows from the open mud. The percentage of AFDW of mud obtained inside burrows in the Spartina-dominated marsh $(x=6.35 \%, S D=2.18$, $\mathrm{n}=20$ ) was not different from the percentage found inside burrows in the mud flats $(x=5.25 \%, \mathrm{SD}=0.81, \mathrm{n}=$ $\left.20 ; t_{\mathrm{c}}=2.15, \mathrm{df}=24, p>0.05\right)$, although their variances were significantly different $(F=7.24, \mathrm{p}<0.05)$. The difference in variability was due to pieces of macrophytes found in burrows from the marsh samples.

Stomach contents of crabs differ between sites (Fig. 6). All individuals from the marsh area showed the stomach full of macrophytes (mean volume $x=$ $0.148 \mathrm{ml}, \mathrm{SD}=0.1518, \mathrm{n}=40$ ), while only $9 \%$ of them showed sediment in their stomach, which always occupied a low volume (mean volume $x=0.002 \mathrm{ml}, \mathrm{SD}=$ $0.003, n=40$ ). The opposite pattern was found with stomach content of individuals from the mud area (mean volume of macrophytes $x=0.0018 \mathrm{ml}, \mathrm{SD}=$ $0.0048, \mathrm{n}=40, t_{\mathrm{c}}=4.28, \mathrm{df}=39, \mathrm{p}<0.05$; mean volume of mud $x=0.051 \mathrm{ml}, \mathrm{SD}=0.0250, \mathrm{n}=40, t_{\mathrm{c}}=8.1, \mathrm{df}=40$, $\mathrm{p}<0.05$ ).

\section{DISCUSSION}

Individuals of Chasmagnathus granulata from the Spartina-dominated marsh and mud flats differ in 
trophic mode, sediment processing rate, burrow architecture and burrow dynamics. Crabs were herbivorous when associated with the cordgrass $S$. densiflora, and deposit feeders when living in tidal creeks and channels. The burrow dynamics and the sediment processing rate was much higher in mud flats than in the marsh, and similarly to thalassinidean shrimps (Griffis \& Suchanek 1991, Nickell \& Atkinson 1995, Rowden \& Jones 1995) trophic modes, burrow architecture and sediment processing rates are associated

Herbivory and deposit-feeding have significantly different effects on the biological and physico-chemical environment. Deposit or detritus feeders can decrease the amount of entrained organic matter in the sediment available to other species (Bird 1982, Suchanek 1985), and control sediment grain size, transport, mixing and deposition (Robertson \& Pfeiffer 1982, Suchanek 1983, Tudhope \& Scoffin 1984). Sediment processing, as inferred from sediment mound size, was much higher in the mud flat than in the marsh area. Based on mound size as an indication of the rate of sediment processing (assuming absence of effect of tidal currents; F. Botto pers. obs.), assuming 40 active burrows $\mathrm{m}^{-2} \mathrm{~d}^{-1}$, and taking into account the size frequency distribution of burrows found in each site, we estimate that the amount of sediment removed per day in mud flats is $5.9 \mathrm{~kg} \mathrm{~m}^{-2} \mathrm{~d}^{-1}$ and $2.4 \mathrm{~kg} \mathrm{~m}^{-2} \mathrm{~d}^{-1}$ in the Spartina-dominated marsh area. Although this is a rough estimation, it shows that crab activity has an important effect in both areas and exemplifies the differences in magnitude between these areas. It is also interesting to notice that the amount of sediment processing shown by Chasmagnathus granulata is higher than most reports for thalassinidean shrimps [e.g. Callianassa kraussi, $12.14 \mathrm{~kg}$ (wet) $\mathrm{m}^{-2} \mathrm{~d}^{-1}$ (Branch \& Pringle 1987); C. subterranea, $3.5 \mathrm{~kg}$ (dry) $\mathrm{m}^{-2} \mathrm{yr}^{-1}$ (Witbaard \& Duineveld 1989); C. californiensis $2.7 \mathrm{l}$ (wet) $\mathrm{m}^{-2} \mathrm{~d}^{-1}$ (Swinbanks \& Luternauer 1987); Glypterus armatus, $3.3 \mathrm{~kg}$ (wet) $\mathrm{m}^{-2} \mathrm{yr}^{-1}$ (Vaugelas 1984)], which are the marine benthic organisms with the highest sediment processing rates. The sediment processed in marsh areas appears to be mostly related to burrow expansion or repair, since it was relatively low and crabs did not show sediment in their stomach content. However, the sediment mounds in intertidal areas may be indicative of deposit feeding, since it is a large amount and crabs show sediment in their stomach content.

Burrows were much deeper in the marsh area than in the mud flat. A similar pattern has been reported for other intertidal burrowing species (e.g. Upogebia pusilla, Callianassa californiensis; Dworschak 1987) for which burrows reached greater depths in the upper intertidal than in subtidal areas. In our case individuals were always intertidal, and the end of the burrow was generally the water table, always containing water during the whole tidal cycle. This may be an adaptation to maintain humidity in the marsh area. Burrows are shelters from predation and environmental extremes, provide water for physiological needs and are sites for molting and reproduction. The burrow shortness in the mud flat area may also be related to feeding mode. Deposit-feeding may only be productive if done in the upper oxygenated layer

Burrow contents were also significantly different between habitats; nematodes and ostracods were significantly more abundant in mud flats than in the marsh areas. This pattern may indicate that burrows are passive trapping areas. A field and laboratory study of Uca crab burrows showed a similar pattern (DePatra \& Levin 1989), which suggests that, as for other depressions, meiofauna increases in abundance due to passive accumulation. Burrows in the marsh area are covered by tides only 1 or 2 times a week, while burrows in the mud flats are inundated 1 or 2 times a day. Thus, if burrows are passive trap areas, the difference in water circulation may be sufficient to explain the differences in abundance of meiofauna. However, even though meiofauna was higher in the mud flat, mean organic matter of burrow contents was not significantly different between habitats, although in the Spartina marsh area AFDW showed larger variability. Larger pieces of plants were occasionally found in burrows located in the marsh, which may be the product of passive transport or have been introduced by crabs. Work in progress (Bortolus \& Iribarne 1996. 1997 ) shows that in this area plants located near burrows (e.g. Spartina densiflora) suffer much higher losses due to crab herbivory than those located in areas without crabs.

Differences in burrow architecture associated with different sediment characteristics may reflect structural limitations of the sediment to support particular type of burrow shape (Griffis \& Suchanek 1991). Burrow morphology may also be related to sediment type (Frey et al. 1978, Griffis \& Chavez 1988). Callianassa pontica excavate burrows with irregular patterns in fine sands, and simple tunnels in coarse sands (Dworschak 1987). In our study the 2 habitats also have different sedimentary composition. While the tidal mud flat is characterized by a high percentage of silt and clay $(52 \%)$ and high penetrability $\left(1.7 \mathrm{kp} \mathrm{cm}^{-2}\right)$, the marsh area is characterized by sand (98\%) and lower penetrability (12 kp cm $\mathrm{cm}^{-2}$ Spivak et al. 1994). Griffis \& Suchanek (1991) suggest that different burrow architecture may also be indicative of different feeding behaviors associated with different sediment types. In fact, there is not necessarily cause and effect in the association between burrow shape and feeding mode; however, sediment characteristics may restrict 
the type of burrow that can be constructed and consequently the type of food to be used.

The differences in architecture between burrows constructed in mud flats and the marsh area may also be related to dissimilarities in the associated food content of the substratum and feeding type. Sediments in the mud flats have much higher organic content (Spivak et al. 1994). If crabs are deposit feeders, they may be depleting the food content of the sediment, and individuals in the mud flats may be forced to construct burrows, or expand their burrows, to support their energetic requirements. Several lines of evidence suggest that burrows in intertidal mud flats increase the ability to trap organic matter. The burrow entrances are different between sites, being funnel-shaped in the mud flat area and straight tunnels in Spartina marshes. The funnel shape entrance has been suggested to function as a sediment trap in thalassinidean shrimps (Suchanek 1983, Poore \& Suchanek 1988, Witbaard \& Duineveld 1989, Vaugelas 1990, Nickell \& Atkinson 1995) by enhancing capture of bedload particles that slip down the sides of the funnel. The increase in the size of the surface openings may also be related to opportunistic trapping of surface-deposited detritus that increases the food content of the sediment. A laboratory flume study suggested that large Uca-mimic burrows in the field should contain higher abundances of passively transported meiotauna than small or upright burrows (DePatra \& Levin 1989). The angle of the tunnel at the entrance also varies between sites, being mainly vertical in the marsh area but oblique in the mud flat. Oblique tunnels allow access to the sediment surface for the movement of sediment or macroorganic materials in or out of the burrow and would thus also suggest a deposit-feeding or omnivorous-scavenging trophic mode (Nickell \& Atkinson 1995). The flume study performed by DePatra \& Levin (1989) also suggested that angled burrows should capture a higher abundance of passively transported meiofauna than upright burrows. Thus, all of this evi dence strongly suggests that the funnel-shaped and inclined burrows found in mud flats are adaptive for deposit feeding.

Burrow mounds were preferentially located upstream or downstream of the major current direction. We have no evidence for their role, but like any other object protruding from the bed, these mounds should change near-bed circulation, increasing shear stress and thus erosion (e.g. Eckman et al. 1981). However, depressions in surface sediments enhance the deposition of suspended material by decreasing shear stress (DePatra \& Levin 1989) and may serve as traps for bedload sediment and organisms. All this evidence suggests that crab burrow architecture may have adaptive significance in several ways, which merit further stud- ies. However, given the extensive intertidal areas in habited by Chasmagnathus granulata in SW Atlantic estuaries, the effect of their burrows as modifiers of nearbed fluxes should not be underestimated. Indeed all evidence suggests that these extensive burrow beds that are distributed between marshes and the open estuary may also be considered a large macrodetritus retention area, reducing the amount of organic matter exported from marshes.

Acknowledgements. This projeci was supported by the Universidad Nacional de Mar del Plata, Fundacion Antorchas (\#13016/1-00012) and International Foundation for Sciences (No. A/2501-1). F.B. was supported by a CONICET (Argentinal Scholarship. We are grateful to the anonymous reviewers for many valuable suggestions.

\section{LITERATURE CITED}

Auster PJ, Crockett LR (1984) Foraging tactics of several crustacean species for infaunal prey. J Shellfish Res 4 : $139-143$

Bertness MD (1985) Fiddler crab regulation of Spartina alterniflora production on a New England salt marsh. Ecology 66:1042-1055

Bertness MD, Miller T (1984) The distribution and dynamics of Uca pugnax (Smith) burrows in a New England salt marsh. J Exp Mar Biol Ecol 83:211-237

Billıck I, Case TJ (1994) Higher order interaction in ecological communties: what are they and how can they be detected? Ecology 75:1529-1543

Bird EW (1982) Population dynamics of the thalassinidean shrimps and their community effects through sediment modification. PhD dissertation, University of Maryland, College Park

Bortolus A, Iribarne O (1996) Efectos del cangrejo ravador Chasmagnathus granulata sobre suelos y comunidades vegetales de marismas. ItI Encontro de especialistas am Decapoda Brachyura, Rio Grande, Brasil. p 1 (Abstract)

Bortolus A. Iribarne O (1997) Interacciones entre el cangrejo cavador Chasmagnathus granulata y un espartillar bonaerense. In: XVIII Reunión de la Asociación Argentına de Ecología, Buenos Aires, Argentina. p 19 (Abstract)

Boschı EE (1964) Los Crustáceos Decápodos Brachyura del Iitoral Bonaerense (R. Argentina). Bol Inst Biol Mar Mar del Plata 6:1-99

Boschı EE (1988) El ecosistema estuarial del Rio de la Plata Argentina y Uruquay. An Inst Cienc Mar Limnol Univ Nac Auton Mex 15: 159-182

Botto JL, ingoyen HR (1979) Bioecologia de la comunidad del Cangrejal. I. Contribucion al conocimiento biologico del cangrejo de estuario, Chasmagnathus granulata Dana (Crustacea, Decapoda, Grapsidae) en la desembocadura del Rio Salado. Provincia de Buenos Aires. Seminario de Biologia Bentonica y Sedimentacion de la Plataforma Continental del Atlantico Sur. UNESCO, Montevideo, p 161-169

Branch GM, Pringle A (1987) The impact of the sand prawn Callianassa kraussi Stebbing on sediment turn-over and the bacteria, meiofauna, and the benthic microflora. J Exp Mar Biol Ecol 107:219-235

Capitoli R, Benvenuti CE, Gianuca NM (1977) Ocorrencia e observacoes bioecologicas do caranguejo Metasesarma 
rubripes (Rathbun) na regiao estuarial da Lagoa dos Patos. Atlantica, Rio Grande 2:50-62

Capitoli R, Benvenuti CE, Gianuca NM (1978) Estudos de ecologia bentonica na regiao estuarial da Lagoa dos Patos. I - As comunidades bentonicas. Atlantıca. Rio Grande 3. $5-22$

Conover WJ (1980) Practical nonparametric statustics, 2nd edn. John Wiley \& Sons, New York

DePatra KD. Levin LA (1989) Evidence of the passive depos1tion of meiofauna into fiddler crab burrows. J Exp Mar Biol Ecol 125:173-192

D'Incao F, Ruffino ML, Silva KG (1988) Notas preliminares sobre a ecologia de Chasmagnathus granulata Dana, 1851 na barra de Rio Grande, RS (Decapoda, Grapsidae). In: Congresso Brasileiro de Zoologia, 15, Curitiba, p 92 (Abstract)

D'Incao F, Ruffino ML, Silva KG, Braga AC (1990) Habito alımentar do cangrejo Chasmagnathus granulata Dana, 1851 na barra de Rio Grande, RS (Decapoda, Grapsidae) Atlantica, Rio Grande 1:85-93

Dworschak PC (1987) Feeding behaviour of Upogebra pusilla and Callianassa tyrrhena. Invest Pesq 51:421-429

Eckman JE, Nowell ARM, Jumars PA (1981) Sediment destabilization by animal tubes. J Mar Res 39:361-374

Fasano JL, Hernandez MA. Isla FI, Schnack EJ (1982) Aspectos evolutivos y ambientales de la laguna Mar Chiquita (provincia de Buenos Aires, Argentina). Oceanol Acta, No. Spec, 285-292

Frey RW, Howard JD, Pryor WA (1978) Ophimorpha: its morphologic, taxonomic and environmental significance. Paleogeogr Paleoclimatol Palaeoecol 23:199-229

Goya M (1988) La construccion de cuevas del cangrejo Chasmagnathus granulata en la laguna de Mar Chiquita. Thesis, Univ Nacional de Mar del Plata

Griffis RB. Chavez Fl. (1988) Effects of sediment type on burrows of Callianassa callorniensis Dana and C. gigas Dana. J Exp Mar Biol Ecol 117:239-253

Griffis RB, Suchanek TK (1991) A model of burrow architecture and trophic modes in thalassinudean shrimps (Decapoda: Thalassinidea). Mar Ecol Prog Ser 79:171-183

Levinton JS (1989) Deposit feeding on coastal oceanography. In: Lopez G. Taghon G, Levinton J (eds) Ecology of marine deposit feeders. Lecture notes on coastal and estuarine studies. Springer-Verlag, New York, p 1-23

Kneib RT (1991) Indirect effects in expermmental studies of marine soft-sediment communities. Am Zool 31:874-885

Kneib RT (1995) Behaviour separates potential and realized effects of decapod crustaceans in salt marsh communities J Exp Mar Biol Ecol 193:239-256

Lanfredi NW, Balestrini CF, Mazio CA, Schmidt SA (1987) Tidal sandbanks in Mar Chiquita coastal lagoon, Argentina. J Coast Res 3:515-520

Montague CL (1980) A natural history of temperate Western Atlantic fiddler crabs (genus $U_{C a}$ ) with reference to their impact on the salt marsh. Contrib Mar Sci 23:25-55

Nickell LA, Atkinson RJA (1995) Functional morphology of burrows and trophic modes of three thalassinidean shrimp species, and a new approach to the classification of thalassinidean burrow morphology. Mar Ecol Prog Ser 128: $181-197$

Olivier SR, Escofet A, Penchaszadeh P, Orensanz JM (1972a)

This article was submitted to the editor
Estudios ecológicos de la regıon estuarial de Mar Chiquita (Buenos Aires, Argentina). 1: Las comunidades bentónicas. An Soc Cient Argent 193:237-262

Olivier SR, Escofet A, Penchaszadeh P, Orensanz JM (1972b) Estudios ecológicos de la region estuarıal de Mar Chiquita (Buenos Aires, Argentına). II. Relaciones troficas. An Soc Clent Argent 194:84-104

Poore GCB, Suchanek TH (1988) Glypturus motupore, a new callianassid shrimp (Crustacea: Decapoda) from Papua New Gunnea with notes on its ecology. Rec Aust Mus 40: $197-204$

Rhoads DC (1967) Bıogenic reworkıng of intertidal and subtidal seduments in Barnstable Harbor and Buzzard Bay, Massachusetts. J Geol 75:461-467

Robertson JR, Pfeiffer W (1982) Deposit-feeding by the ghost crab Ocypode quadrata (Fabricius). J Exp Mar Biol Ecol $56: 165=177$

Rowden AA, Jones MB (1995) The burrow structure of the mud shrimp Callianasa subterranea (Decapoda: Thalassunidea) from the North Sea. J Nat Hist 29:1155-1165

Spivak E, Anger K, Luppi T. Bas C, Ismael D (1994) Distribution and habitat preferences of two grapsid crab species in Mar Chiquita Lagoon (Province of Buenos Aires, Argentina). Heigoländer Meeresunters 48:59-78

Suchanek TH (1983) Control of seagrass community and sediment distribution by Callianassa (Crustacea, Thalassinidea) bioturbation. J Mar Res 41:281-298

Suchanek TH (1985) Thalassinid shrimp burrows: ecological significance of species-specific architecture. Proc 5th $\ln t$ Coral Reef Congr Tahiti 5:205-210

Swinbanks DD, Luternauer JL (1987) Burrow distribution of thalassinidedn shrimp on a Fraser delta tidal flat. Britısh Columbia. J Paleontol 61:315-332

Teal JM, Kanwisher J (1961) Gas exchange in a salt marsh. Limnol Oreanogr 6:388-399

Thrush SF (1988) The comparison of macrobenthic recolonization pattern near and away from crab burrows on a sublittoral sand flat. J Mar Res 46:669-681

Tudhope AW, Scoffin TP (1984) The effects of Callanassa bioturbation on the preservation of carbonate grains in Davies Reef Lagoon, Great Barrier Reef, Australia. J Sediment Petrol 54:1091-1096

Vaugelas JV de (1984) Preliminary observations on two types of callianassids (Crustacea; Thalassinidea) burrows, Gulf of Aqaba (Red Sea). Proc 1st Int Symp Coral Reef Environ Red Sea 1:520-539

Vaugelas JV de (1990) Ecologie des callianasses (Crustacea, Decapoda, Thalassinidea) et mlleu récifal Indo-Pacifique. Conséquences du remaniement sédimentaire sur la distribution des matieres humıques, des métaux trace et des radionucléides. Memoire présenté a l'Université de Nice

Warwick RM, Clarke KR, Gee JM (1990) The effect of disturbance by soldier crabs Mictyris platycheles $H$. Milne Edwards on meiobenthic community structure. J Exp Mar Biol Ecol 135:19-33

Witbaard R, Duineveld CCA (1989) Some aspects of the biology and ecology of the burrowing shrimp Callianassa subterranea (Montagu) (Thalassindea) from the southern North Sea. Sarsia 74:209-219

Zar JH (1984) Biostatistical analysis. Prentice-Hall, Englewood Cliffs, NJ

Manuscript received: April 7, 1997

Revised version accepted: June 25, 1997 